
process, such as peer review, editing, corrections, structural formatting, and other quality control mechanisms may not be reflected in this document. Changes may have been made to this work since it was submitted for publication. A definitive version was subsequently published in Domene, X., et al. "Short-term mesofauna responses to soil additions of corn stover biochar and the role of microbial biomass" in Applied soil ecology (Elsevier), vol. 89 (May 2015), p. 10-17. DOI 10.1016/j.apsoil.2014.12.005

\title{
Short-term mesofauna responses to soil additions of corn stover biochar and the
} role of microbial biomass

\author{
Xavier Domene ${ }^{1,2,3}$, Kelly Hanley ${ }^{3}$, Akio Enders ${ }^{3}$, Johannes Lehmann ${ }^{3,4}$ \\ ${ }^{1}$ CREAF, Cerdanyola del Vallès 08193, Spain \\ ${ }^{2}$ Universitat Autònoma Barcelona, Cerdanyola del Vallès 08193, Spain \\ ${ }^{3}$ Department of Crop and Soil Sciences, Cornell University, Ithaca, NY 14853, USA \\ ${ }^{4}$ Atkinson Center for a Sustainable Future, Cornell University, Ithaca, NY 14853, USA
}

Keywords: biochar, soil fauna, behavior, avoidance, microbial biomass, ammonium

\begin{abstract}
Biochar additions have been suggested to influence soil microbial communities that, through a cascade effect, may also impact soil fauna. In turn, any direct biochar effects on fauna can influence microbial communities through grazing, physical fragmentation of organic debris (and biochar) and modifying soil structure. If biochar creates a favorable environment for soil microorganisms, it is also plausible for fauna to be attracted to such microbially enriched habitats. However, how soil fauna respond to biochar addition to soil and what are the main factors that drive their behavior has rarely been experimentally addressed. Therefore, the behavior of two mesofauna species was assessed as a result of corn stover biochar (slow pyrolysis at $600^{\circ} \mathrm{C}$ ) additions to a loamy temperate soil, after preincubation for 2, 17, 31 and $61 \mathrm{~d}$, and related to variations in microbial biomass and activity. Microbial biomass increased by $5-56 \%$ and activity by 6-156\% with increasing biochar rates for the different preincubation times. Over the incubation time, microbial biomass did not change or increased at most $15 \%$ with the different biochar rates, while in turn microbial activity decreased steadily (around 70-80\% at day 61). Enchytraeids generally did not show avoidance or preference to biochar when provided with an alternative unamended soil, while collembolans often showed avoidance responses. However, collembolan avoidance to
\end{abstract}


biochar decreased or disappeared in biochar mixtures with higher microbial biomass and soluble $\mathrm{NH}_{4}-\mathrm{N}$ content, agreeing with the plausible role of microorganisms to potentially attract soil fauna after biochar applications. Avoidance response was mainly explained by environmental preferences of the test species and not by any toxic effect of the biochar in this study. However, avoidance after the application of biochar may still need to be considered due to the potential negative impacts of individuals' migration on soil ecosystem functioning.

\section{INTRODUCTION}

The addition of some biochars has been found to stimulate microbial abundance and activity (Pietikäinen et al. 2000, Steiner et al 2004, Birk et al. 2009), which could then potentially influence nutrient cycles and crop productivity (Güereña et al. 2013). However, the literature about potential direct and indirect effects on soil fauna other than earthworms is scarce. This is surprising due to the key role of soil biota in some of the reported beneficial effects of some biochars on soil fertility (Lehmann et al. 2011) as well as the suspected effect of fauna on biochar persistence in soil, e.g. the reported capacity of earthworms to ingest and grind biochar particles, and to excrete biochar complexed with minerals (Topoliantz and Ponge 2005, Ponge et al. 2006).

Some positive effects on biota activity have been described in char-rich soil layers in burnt areas, observed as abundant fungal hyphae, as well as fresh and reprocessed fauna fecal pellets (Bunting and Lundberg 1987, Phillips et al. 2000). Positive effects have also been predicted for bacterivore soil fauna groups in acid soils after the $\mathrm{pH}$ increase associated with biochar applications that favor bacteria (McCormack et al. 2013). Data from loamy temperate soils cropped to corn confirm enhanced faunal activity three years after the addition of increasing rates of biochar (3 to $30 \mathrm{Mg} \mathrm{ha}^{-1}$ ), but only in combination with certain soil properties (Domene et al. 2014). Zhang et al. (2014) reported no variation in total nematode abundance after a wheat straw biochar addition of $2.4 \mathrm{Mg} \mathrm{ha}^{-1}$, though higher diversity with biochar addition was observed as well as an increased abundance of fungivores. However, negative effects have also been occasionally observed, such as decreased faunal activity in an alkaline soil cropped to barley and amended at high addition rates (50 $\left.\mathrm{Mg} \mathrm{ha}^{-1}\right)$ with a gasification pine wood biochar (Marks et al. 2013). 
The mechanisms underlying any of these effects have not been clearly demonstrated yet, although positive effects could at least partly be due to trophic effects resulting from biochar effects on soil microbial communities that certain fauna rely on. If microbial abundance is affected by biochar application, a cascade effect is expected on all soil fauna directly or indirectly relying on them (McCormack et al. 2013). In turn, effects on fauna could influence microorganisms themselves, due to the fauna regulation of organic matter decomposition by microbial grazing, but also by indirect effects resulting from litter fragmentation and soil structure modification carried out by some faunal groups (Bardgett 2005).

Several explanations have been linked to the increased microbial abundance after biochar addition. Some authors have pointed out the refuge for microorganisms provided by biochar porosity (Lehmann et al. 2011, Ennis et al. 2012), while others have also suggested the increased nutrient and carbon availability and water retention around biochar, the sorption of noxious chemicals, and the increased $\mathrm{pH}$ in the specific case of acid soils (Lehmann et al. 2011). On the other hand, Pietikäinen et al. (2000) proposed the reduction of microbial cell leaching by direct retention in biochar as explanation.

Scarce evidence exists about how fauna interact with biochar particles or soils to which biochar was added. Data are mostly obtained with earthworms in avoidance tests, by introducing individuals in a vessel containing soil and a soil-biochar mixture and assessing their distribution after a period of time. Avoidance tests with soil fauna are based on the ability of organisms to escape from unsuitable environments due to pollution (Amorim et al. 2005, Loureiro et al. 2005, Lukkari et al. 2005, Natal-daLuz et al. 2008a) or due to unsuitable environmental conditions outside their ecological preferences (Natal-da-Luz et al. 2008b, Chelinho et al. 2011, Domene et al. 2011). Avoidance tests are based on the chemoreception capacity of most soil animals and have a high ecological relevance (Natal-da-Luz et al. 2009) since avoidance responses under field conditions are equivalent to mortality in terms of ecosystem composition and function. This is why earthworm avoidance tests, together with plant germination tests, have been proposed as quick screening tests for the ecotoxicological characterization of biochars before their use in the field (Major 2009). Conversely, avoidance test methods, initially designed for pollutant testing, allow the detection of 
preference behavior for practices enhancing the soil function as habitat such as the addition of biochars.

The type of feedstock, the pyrolysis procedure used, and the rate of addition are the most plausible factors that could explain faunal responses to biochar, but also the type of soil and changes in soil properties caused by biochar addition. As an example, Van Zwieten et al (2010), comparing the response of earthworms (Eisenia andrei) in soil mixtures of two slow pyrolysis papermill waste biochars in an acid and an alkaline soil (10 $\mathrm{Mg} \mathrm{ha}^{-1}$, equivalent to a 2 and $1.5 \%$ addition, respectively), demonstrated preference for soil-biochar mixtures in the acid soil but not in the basic soil. This behavior was associated with a $\mathrm{pH}$ increase (from 4.2 to around 5.13-5.93) and higher microbial activity after the addition of biochar to the acid soil, and not observed in the basic soil. Preference response was assumed to be the result of a more suitable environment for this species and pointed out the importance of the type of soil for evaluating the impact of biochar addition on soil biota. Excessive liming has also been linked to toxic effects of e.g. a poultry biochar (Liesch et al. 2010), which might have been detected with avoidance responses. Li et al. (2011) reported that the avoidance by the earthworm Eisenia fetida for an apple wood sawdust biochar was entirely explained by water content in soil-biochar mixtures, since avoidance disappeared when moisture was adjusted to field capacity.

The appeal of soil fauna for biochar has been inferred from field observations in biochar-enriched soils after wildfires (Topoliantz and Ponge 2005, Ponge et al. 2006), and plausibly explained by microbial abundance, although this has been rarely addressed experimentally in the available literature, with a few studies based only on earthworm species. A variety of responses have been reported in them, ranging from preference (Zwieten et al 2010, Busch et al. 2012, Hale et al. 2013, Chan et al. 2008), to no effect or avoidance (Chan et al. 2008, Liesch et al. 2010, Li et al. 2011, Zwieten et al 2010, Tammeorg et al. 2014), although these studies have not checked or had failed to empirically find a correlation with microbial abundance.

The main aim of this study was to assess the main drivers for the behavior of two soil mesofauna species exposed to soil-biochar mixtures, which may be representative for the potential short-term responses of soil fauna under field conditions. We hypothesized that a relationship of such a response exists with microbial biomass and activity. 


\section{METHODS}

\subsection{Mesofauna species, soil and biochar}

The test species of this study were considered to be representative of soil mesofauna due to their contrasting feeding and life habits and exposure routes. Folsomia candida is a predominantly fungivorous species living in soil pores (Fountain and Hopkin 2005), while Enchytraeus crypticus lives in close contact with soil pore water (Römbke 2003) as most enchytraeids do and mostly feeds on bacteria and plant debris (Didden and Römbke 2001).

An agricultural soil cropped to corn was collected at the Cornell Musgrave Research Farm (Aurora, New York, USA) in early spring 2008. Soil had a 42\% sand, 31\% silt and $27 \%$ clay, total $\mathrm{C}$ content of $16.2 \mathrm{~g} \mathrm{~kg}^{-1}$, total $\mathrm{N}$ of $1.6 \mathrm{~g} \mathrm{~kg}^{-1}$, and a $\mathrm{pH}$ around 7.3 (see Rajkovich et al. 2012 more details). Soil was collected after snowmelt and before any fertilizer or pesticide was applied, and then air-dried, homogenized, and sieved to 5 $\mathrm{mm}$. Soil was defaunated by long-term storage (two years), and by carrying out two freezing-thawing cycles $\left(24 \mathrm{~h}\right.$ at $-20^{\circ} \mathrm{C}, 24 \mathrm{~h}$ at $20^{\circ} \mathrm{C}$ ) before the beginning of the experiment. The corn stover biochar in this study was produced by slow pyrolysis (30 min, $600^{\circ} \mathrm{C}$ ) at BEST Energies Inc. (Somersby, Australia). Biochar had a high alkalinity $(\mathrm{KCl} \mathrm{pH}=10)$ and intermediate volatile matter content (26\%) (see Güereña et al. 2013 for this and additional details on biochar composition).

\subsection{Avoidance test setup}

Avoidance tests in both species were carried out in accordance with ISO (2011), a test initially designed for $F$. candida. The only modification for collembolans was that individuals were aged 24-32 days instead of the 10-12 days proposed in the test to maximize their recovery at the end of the test. E. crypticus was continuously cultured so the availability of clitellated adults was ensured during the experiment.

Soil-biochar mixtures $(0,0.2,0.5,2,7$ and $14 \%$ w/w) were prepared and moistened to $50 \%$ of the maximum water holding capacity. Moistening was carried out with deionised water containing $5 \%(\mathrm{v} / \mathrm{v})$ of an inoculant solution to reintroduce the 
indigenous microorganism communities. The inoculant solution was prepared with fresh soil taken from the same field plots where the test soil was collected two years before, and consisted of the supernatant of a soil-water slurry (1:10), stirred for 5 min at $150 \mathrm{rpm}$, settled for $5 \mathrm{~min}$, decanted, and centrifuged for $5 \mathrm{~min}$ at $3000 \mathrm{x} \mathrm{g}$. Before using soil-biochar mixtures in the avoidance tests, mixtures were preincubated for 2,17 , 31 and $61 \mathrm{~d}$ in 1-L glass jars. A separate mixture was prepared for each soil-biochar concentration and preincubation time to avoid any disturbance due to sampling.

At each preincubation time, the incubated mixtures were destructively sampled to set up the avoidance tests and to analyze their microbial and chemical properties. For each species, six replicates per soil-biochar mixture were prepared. Two additional replicates were prepared for the assessment of basal soil respiration and microbial biomass, two for the preparation of aqueous extracts for the assessment $\mathrm{pH}$, electrical conductivity (EC) and soluble ion content, and one to assess moisture.

Avoidance tests were carried out in translucent plastic vessels (115 mm diameter x 60 $\mathrm{mm}$ height for collembolans, and $57 \mathrm{~mm}$ diameter $\mathrm{x} 73 \mathrm{~mm}$ height for enchytraeids). The vessel was filled with two adjacent wet soil portions (30 g in collembolans and $20 \mathrm{~g}$ in enchytraeids) each occupying half the container, and consisting of control soil and the tested soil-biochar mixture. Then, 20 individuals were transferred to the centre of the container, and left under controlled climatic conditions $\left(20 \pm 2^{\circ} \mathrm{C}\right.$ and in the dark) for 48 $\mathrm{h}$ for collembolans and $72 \mathrm{~h}$ for enchytraeids. After this period, each soil portion was taken separately and abundance of individuals on each side was determined. For collembolans, each portion was poured into a 200-mL Erlenmeyer flask and flooded with water. Soil was gently stirred in order to force the individuals to float on the water surface and enable visual counting. For enchytraeids, individuals were fixed with 75\% ethanol and dyed with a 1\% Bengal red alcohol solution for $24 \mathrm{~h}$, then passed though a 0.2 mm-mesh sieve and counted by eye (adapted from Römbke and Moser 2002).

Avoidance (A) was expressed as percentage and calculated as $A=((C-T) / N) * 100$, where $\mathrm{C}$ corresponds to the number of individuals in the control soil, $\mathrm{T}$ is the number of individuals in the test soil, and $\mathrm{N}$ corresponds to the total number of individuals collected at the end of the experiment, i.e. $\mathrm{C}+\mathrm{T}$. The test is invalid if more than 4 individuals per vessel (20\%) are dead or missing at the end of the test. A zero value corresponds to an equal distribution on each side, while positive values indicate avoidance to a given soil-biochar mixture, and negative values a preference behavior. 
Moisture was assessed gravimetrically by drying at $105^{\circ} \mathrm{C}$ for $12 \mathrm{~h}$ a $20 \mathrm{~g}$ moist sample. Basal soil respiration was assessed by adding $20 \mathrm{~g}$ of moist mixture to a polyethylene vessel placed in a 500-mL glass jar containing another polyethylene vessel filled with $\mathrm{NaOH}$ and incubating for $24 \mathrm{~h}$ at $20 \pm 1^{\circ} \mathrm{C}$, according to the titration method described in Pell et al. (2006). Microbial biomass was assessed in the same mixture at the end of this period according to the fumigation-extraction method described in Brookes and Joergensen (2006). Aqueous extracts were prepared by a 30-min horizontal shaking at $160 \mathrm{rpm}$ of a 1:5 w/v solution (20 g fresh soil in $100 \mathrm{ml}$ water), centrifugation for $5 \mathrm{~min}$ at $3600 \mathrm{~g}$, and filtration through Whatman \#1 filter paper. The $\mathrm{pH}$ and electrical conductivity (EC) were immediately assessed and extracts rapidly frozen at $-20^{\circ} \mathrm{C}$ until further analyses. Water soluble $\mathrm{Cl}^{-}, \mathrm{Br}^{-}, \mathrm{SO}_{4}-\mathrm{S}, \mathrm{NO}_{2}-\mathrm{N}, \mathrm{NO}_{3}-\mathrm{N}$ were analyzed using an ICS-2000 ion chromatograph (Dionex, Sunnyvale, CA, USA), while soluble $\mathrm{PO}_{4}-\mathrm{P}$ was measured as soluble reactive phosphorus (SRP) in a flow analyzer (FS 3000, OI Analytical, College Station, TX) using the ascorbic acid and molybdate method. Soluble $\mathrm{NH}_{4}-\mathrm{N}$ was measured by the phenate method as described in APHA-AWWA-WPCF (1985).

\subsection{Ecotoxicological and chemical properties of the soil-biochar mixtures}

In parallel to the avoidance tests, collembolan and enchytraeid reproduction tests were carried out to assess any potential ecotoxicological effects of the biochar in this study according to standardized protocols (ISO (1999) and ISO (2004), respectively). The same soil-biochar mixtures used for the avoidance tests were identically prepared and inoculated. For each species, six replicates were prepared per soil-biochar mixture, each consisting of a 125-mL polyethylene vessel (57 mm diameter x $73 \mathrm{~mm}$ height), filled with 30 g of soil-biochar mixture moistened to $50 \%$ of its water holding capacity.

Ten juveniles of the corresponding species were placed in each vessel and food was added, consisting of baker's yeast in collembolan tests and ground oat flakes in enchytraeid tests. Vessels were covered with a lid and incubated for $28 \mathrm{~d}$ at $21^{\circ} \mathrm{C}$ in the dark. The individuals were fed periodically, and the replicates aerated, as described in the protocol. At the end of this period, collembolan vessels were flooded and a picture of the surface was taken to allow counting the adults and juveniles present. In the enchytraeid tests, individuals were fixed with $75 \%$ alcohol and stained with 10 drops of 
a $1 \%$ Bengal red solution in alcohol for $24 \mathrm{~h}$, and then sieved to $0.2 \mathrm{~mm}$ by adding tap water to allow counting of the dyed adults and juveniles.

Two additional replicates were prepared per soil-biochar mixture and incubated at $21^{\circ} \mathrm{C}$ for $28 \mathrm{~d}$ to assess soil chemical properties at the end of the test. Namely, 1:5 w/v aqueous extracts were prepared and $\mathrm{pH}, \mathrm{EC}$, soluble ion content, assessed as described for the avoidance test mixtures. Soluble elemental content (Al, As, B, Ba, Ca, Cd, Co, $\mathrm{Cr}, \mathrm{Cu}, \mathrm{Fe}, \mathrm{K}, \mathrm{Mg}, \mathrm{Mn}, \mathrm{Mo}, \mathrm{N}, \mathrm{Na}, \mathrm{Ni}, \mathrm{P}, \mathrm{Pb}, \mathrm{S}$, Se, Si, Sr, Ti, V, Y, and Zn) was assessed by ICP-ES in a 61E ICP trace analyzer (Thermo Jarrell Ash Co, Franklin, MA).

\subsection{Statistical assessment}

All statistical analyses were conducted using R software version 2.15 (R Foundation for Statistical Computing, Vienna, Austria). In the reproduction tests, the effect of biochar addition rates on survival and reproduction (expressed as percent of the performance in control) was assessed by one-way ANOVA. The significant differences in these endpoints between unamended soil and each soil-biochar mixture were verified by the Bonferroni test.

Significant avoidance or preference behavior was examined for each soil-biochar mixture and incubation time with a two-tailed Fisher's exact test (fisher.test function in $\mathrm{R})$. This test is based on comparison of the expected number of individuals at each side (half of them) and the actual distribution observed, having as null hypothesis an equal distribution on both sides (i.e. no avoidance or preference behavior).

The influence of the biological and chemical properties assessed in the different soilbiochar mixtures and incubation times on avoidance was assessed by Generalized Linear Models (GLM). $\mathrm{NO}_{2}-\mathrm{N}$ and $\mathrm{NO}_{3}-\mathrm{N}$ were combined due to the relatively low concentration and the transient nature of $\mathrm{NO}_{2}-\mathrm{N}$ in soil. The values for microbial and chemical properties were standardized by dividing the values in the biochar mixtures by the value in the corresponding control at each incubation time. Values over 1 indicate higher values in the biochar-mixture, while values below 1 imply higher values in the control soil. This approach has been shown to be useful for the analysis of avoidance 
data (Chelinho et al. 2011, Domene et al. 2011), since the choice or rejection of the test soil is influenced by the magnitude of the differences compared to the control soil.

GLM were constructed for the avoidance response of mesofauna species, one using the unstandardized microbial and chemical properties in soil-biochar mixtures and the other using the standardized values. In both cases, a global GLM was constructed assuming a Gaussian distribution ( $\mathrm{glm}$ function, stats package in R). Then, using the vif function of the $\mathrm{HH}$ package in $\mathrm{R}$, variables showing high multicollinearity were consecutively removed until all variables showed VIF values below 5 . Then, the best model was selected using the dredge function of the MuMIn package in $\mathrm{R}$, which provided the model with lowest AIC.

\section{RESULTS}

\subsection{Fauna interaction with biochar particles and ecotoxicity}

In both the avoidance and reproduction tests individuals of both species ingested biochar particles, easily observed due to its translucent nature as a dark gut content (Supplementary Figure S1, Supplementary Video S1), thereby making possible the utilization of the microbial biomass present in biochar by fauna or an enhanced exposure to detrimental compounds in biochar. Regarding toxic effects, no significant negative effects on the survival of the added adults were observed for any of the two test species after 28d of exposure (Figure 1). Collembolan reproduction was also unaffected by biochar, but enchytraeid reproduction increased significantly at the 0.5 and $2 \%$ application rate (Bonferroni test, $\mathrm{p}<0.05$ ). At the end of the reprodution test, biochar application rates decreased soluble $\mathrm{NO}_{3}-\mathrm{N}$, pH slightly decreased, while specifically EC and soluble $\mathrm{Cl}^{-}, \mathrm{K}^{+}$, and to a lesser extent $\mathrm{Na}^{+}$, increased steadily (Supplementary Table S1).

\subsection{Microbial biomass and activity, and chemical soil properties}

In the soil-biochar mixtures used in the avoidance tests, higher $\mathrm{pH}$ and especially EC were observed as biochar application rates increased (Figure 2). Whereas EC did not vary with incubation time, $\mathrm{pH}$ decreased over time in the unamended soil and in the 
mixtures with biochar. $\mathrm{Cl}^{-}, \mathrm{Br}^{-}$and $\mathrm{SO}_{4}-\mathrm{S}$ concentrations increased with biochar application rate, while $\mathrm{NH}_{4}-\mathrm{N}$ decreased with increasing biochar rates (Supplementary Figure S2). $\mathrm{PO}_{4}-\mathrm{P}$ was higher than in the control only at the highest application rate, while $\mathrm{NO}_{3}-\mathrm{N}$ contents decreased with biochar application rate but were always higher than in control soil. Over time, only $\mathrm{NO}_{3}-\mathrm{N}$ increased in biochar mixtures but not in controls, whereas $\mathrm{NO}_{2}-\mathrm{N}$, Br- , and especially $\mathrm{NH}_{4}-\mathrm{N}$ decreased, irrespective of biochar application rate.

Basal soil respiration values were higher at the highest biochar application rates, but decreased over time at all application rates (Figure 2). Less clear trends were found for microbial biomass, although clearly higher microbial biomass values were observed with $14 \%$ biochar.

\subsection{Avoidance/preference responses}

Avoidance response to biochar mixtures in this study was often observed in F. candida, while preference was never observed, though no strong trends in this response was found regarding the biochar application rate or preincubation time (Figure 3). A general avoidance was observed after $17 \mathrm{~d}$ of incubation except at the $14 \%$ rate, while later during the incubation, avoidance was occasionally observed at the 0.2, 0.5 and 14\% application rates. On the other hand, E. crypticus did not negatively respond to biochar application, but rather a significant preference was observed, though only at the $0.2 \%$ biochar application after $2 \mathrm{~d}$ and at the $7 \%$ after $61 \mathrm{~d}$.

Modeling of the avoidance response of $F$. candida to biochar, microbial biomass and soluble $\mathrm{NH}_{4}-\mathrm{N}$ were able to explain 45 and $67 \%$ of the variance in this response using the unstandardized and the standardized variables, respectively (Table 1). This indicates a lower or a lack of avoidance for biochars the higher the microbial biomass and $\mathrm{NH}_{4}-$ $\mathrm{N}$. In the model with standardized values, $\mathrm{Br}$ was also associated with lower avoidance of biochar, while the opposite was found for higher $\mathrm{pH}$, which increased biochar avoidance. Regarding E. crypticus, the obtained models were not acceptable as they had a very low predictability or did not include any significant variable (Table 2).

\section{DISCUSSION}




\subsection{Chemical factors controlling faunal responses to biochar}

The contribution of $\mathrm{pH}$ to collembolan avoidance in this study is unexpected, since the corn biochar only slightly increased pH (7 to 7.5), in a range not expected to affect avoidance behavior of F. candida (Domene et al. 2011). Similarly, reproduction in this species has been shown to be not affected at this pH (Crouau et al. 1999, Domene et al. 2011). On the other hand, salinity was not included in the models for collembolan avoidance even though reproduction and survival may change in this species at the observed range of salinity (Owojori et al. 2009) which increased from less than 100 to $800 \mu \mathrm{S} \mathrm{cm}^{-1}$. Soluble $\mathrm{Br}$ and $\mathrm{NH}_{4}-\mathrm{N}$ appeared to be positively associated with a reduced avoidance behavior in collembolans. This might be explained by an increased mineralization in soil-biochar mixtures with high microbial biomass, but also a direct positive effect of $\mathrm{NH}_{4}-\mathrm{N}$ is also plausible, since earthworm excreta have been shown to attract some collembolan species (Salmon and Ponge 2001). $\mathrm{NH}_{4}$ is easily converted to volatile $\mathrm{NH}_{3}$ and potentially causes toxic effects on soil fauna (Domene et al. 2010, Liesch et al. 2010), but the low concentrations present in the avoidance test mixtures (Supplementary Table S2) discard this possibility.

Regarding other ions, the only remarkable increase associated with biochar addition is that of $\mathrm{Cl}^{-}$(Supplementary Table S2), although potential effects on avoidance or toxicity for the tested species were not shown in our study. Similar increases in soluble $\mathrm{K}, \mathrm{Ca}, \mathrm{Si}$ and Na were observed in the soil-biochar mixtures used in the reproduction tests (Supplementary Table S1). In F. candida, $\mathrm{Na}^{+}$has been shown to be more toxic than other ions applied at similar concentrations (Schrader et al. 1998), although the increases in $\mathrm{Na}$ observed after biochar addition were not associated with toxic effects. The potential effects on the avoidance response are unknown since soluble Na content in the corresponding mixtures was not assessed.

\subsection{Microbial biomass role on faunal responses to biochar}

While enchytraeid behavior was unaffected by microbial biomass or other assessed properties, in collembolans, the significant contribution of microbial biomass to a decreased avoidance of the tested biochar suggests that microorganisms were compensating for whatever was causing the avoidance observed with this biochar. The contribution of microbial biomass is consistent with its plausible role in stimulating 
faunal activity in biochar-enriched soils. As an example, Van Zwieten et al (2010) suggested that earthworm preference for soil-biochar mixtures observed in an acid soil, but not in an alkaline soil, was associated with increases of both $\mathrm{pH}$ and microbial activity that provided a more suitable environment for the test species. Several mechanisms have been proposed for the increased microbial biomass or activity after biochar addition (Pietikäinen et al. 2000, Lehmann et al. 2011, Ennis et al. 2012), potentially explaining the connection between fauna and biochar. However, Marks et al. (2014) were unable to find a direct link between microbial biomass and stimulatory effects on F. candida reproduction observed in several of the biochars tested, potentially indicating the need for a more refined explanation beyond microbial biomass.

A shift to higher bacteria-to-fungi ratios has been predicted in acid soils with a $\mathrm{pH}$ increase (Bargett et al. 1996). This is why it has been suggested that the application of biochar, as a result of their liming capacity, might increase bacterial biomass, thereby potentially favoring bacterial feeders and their predators (McCormack et al. 2013, Wiedner and Glaser 2013). However, the positive effect of $\mathrm{pH}$ on bacteria-to-fungi ratio is under debate yet, since the opposite trend (Bååth and Anderson 2003) or no effects (Frey et al. 1999) have been reported in other studies. In alkaline soils such as the one in our study, shifts in microbial community composition after the application of fresh biochar are more likely related to the addition of new usable carbon sources, rather than to pH-related shifts. This is plausible in our study, as demonstrated by Jin (2010), who reported drastic changes in both bacterial and fungal diversity measured by TRFLP at the highest application rates (12 and $30 \mathrm{Mg} \mathrm{ha}^{-1}$, equivalent to a 0.5 and a $1.3 \% \mathrm{w} / \mathrm{w}$, respectively) 6-12 months after the application of the same biochar in this study to the same field plots where the soil for this study was collected. The higher reduction in the number and height of bacterial peaks observed with biochar additions compared to fungal peaks suggested a decrease in the bacteria-to-fungi ratios. Although we lack direct measurements of bacteria-to-fungi ratios in soil-biochar mixtures, an increased fungal abundance over that of bacteria might partly explain why F. candida avoidance was attenuated by microbial biomass increases (F. candida is mostly fungivorous according to Moore et al. 1987, Fountain and Hopkin 2005), while the behavior of $E$. crypticus, mostly a bacterivore and detritivore (Didden and Römbke 2001), was unaffected by microbial biomass. 


\subsection{Relationship between avoidance and reproduction tests}

It is also remarkable that the avoidance response observed in collembolans is not associated with negative effects on reproduction, which would indicate chronic toxicity. Similarly, Hale et al. (2013) observed no change in reproduction of F. candida in soil mixtures with the same corn biochar used in our study, while preference was reported in the epigeic earthworm E. fetida, and toxicity was observed in the endogenic worm Aporrectodea caliginosa. All these observations suggest that avoidance response to biochar is highly dependent on the test species used and their particular environmental preferences, but does not necessarily reflect potential chronic toxicity effects of biochar. This remark does not question the usefulness of avoidance tests, since a generalized avoidance after a biochar application might have the same functional effect in soil ecosystems as the loss of faunal abundance or diversity by toxic effects. Our conclusions, though restricted to the tested short period of time and to the soil, biochar and invertebrate species used in this study, highlight the need for more research on biochar and soil fauna interactions.

\section{CONCLUSIONS}

The application of a slow pyrolysis corn stover biochar to a temperate loamy soil affected soil microbial biomass and activity, which increased and declined, respectively, over a 2-month period. Over this period, biochar also caused contrasting effects on the behavior of the two mesofauna species assessed. While enchytraeids were generally equally distributed between unamended and biochar-amended soil, collembolans often showed avoidance responses to biochar. This response was lower or disappeared in soilbiochar mixtures with high microbial biomass and/or soluble $\mathrm{NH}_{4}-\mathrm{N}$ contents, a finding that matches with the previous expectations about the role of microbial biomass on soil fauna distribution in soil and the reported attraction response of some collembolan species to earthworm excreta, respectively. Collembola avoidance to the biochar in this study seemed to be mostly explained by the environmental preferences of the test species rather than by any toxicity, though this response is still informative for potential migration of some soil faunal groups to affect soil ecosystem functioning shortly after the addition of biochar. 


\section{ACKNOWLEDGEMENTS}

The experiments in this study were funded by the Spanish Ministry of Science and Innovation through the CARBONET project (MICINN, CGL2010-15766), while the field soil plots maintenance and the biochar production were funded by the United States Department of Agriculture through a Hatch grant (USDA, NY-125487), the New York State Energy Research and Development Authority (NYSERDA contract 9891), and the National Science Foundation's Basic Research for Enabling Agricultural Development (NSF-BREAD, grant number IOS-0965336).

\section{FIGURE CAPTIONS}

Figure 1. Collembolan and enchytraeid survival and reproduction in soil-biochar mixtures at increasing application rates. Asterisks indicate significant differences in the test organism's performance compared to controls (Bonferroni test, $\mathrm{p}<0.05$ ); $\mathrm{n}=6$.

Figure 2. Basal soil respiration (BAS), microbial biomass, electrical conductivity and $\mathrm{pH}$ in soil-biochar mixtures used in the avoidance tests at increasing application rates over a 2-month incubation; $\mathrm{n}=2$.

Figure 3.Collembolan and enchytraeid distribution (\%) in control soil (white) and in soil-biochar mixtures (grey) with different biochar application rates and preincubation times. Significant deviations from an equal distribution in both sides (i.e. avoidance or preference for the biochar-amended soil) are indicated with an asterisk (Fisher's exact test, $\mathrm{p}<0.05) ; \mathrm{n}=6$. 


\section{REFERENCES}

Amorim, M.J., Römbke, J., Soares, A.M., 2005. Avoidance behaviour of Enchytraeus albidus: Effects of benomyl, carbendazim, phenmedipham and different soil types. Chemosphere 59, 501-510.

APHA-AWWA-WPCF, 1985. Standard Methods for the Examination of Water and Wastewater. 16th edition.American Public Health Association, American Water Works Association and Water Pollution Control Federation, Washington, DC, USA.

Bååth, E., Anderson, T.H., 2003. Comparison of soil fungal/bacterial ratios in a pH gradient using physiological and PLFA-based techniques. Soil Biol. Biochem. 35, 955-963.

Bardgett, R., 2005. The Biology of Soil. A community and ecosystem approach. Oxford Press, Oxford, UK, pp. 70-79.

Bardgett, R.D., Hobbs, P.J., Frostegård, Å., 1996. Changes in soil fungal:bacterial biomass ratios following reductions in the intensity of management of an upland grassland. Biol. Fertil. Soils 22, 261-264.

Birk, J.J., Steiner, C., Teixeira, W.C., Zech, W., Glaser, B., 2009. Microbial response to charcoal amendments and fertilization of a highly weathered tropical soil. In:

Woods,W.I., Teixeira, W.G., Lehmann, J., Steiner, C., Winkler Prins, A.M.G.A, Rebellato, L. (eds) Amazonian Dark Earths: Wim Sombroek’s Vision. Springer, Berlin, pp. 309-324.

Brookes, P.C., Joergensen, R.G., 2006. Microbial biomass measurements by fumigation-extraction. In: Bloem, J., Hopkins, D.W., Benedetti, A. (Eds.), Microbiological Methods for Assessing Soil Quality. CABI Publishing. King's Lynn, UK.

Bunting, B., Lundberg, J., 1987.The humus profile-concept, class and reality. Geoderma 40,17-36. 
Busch, D., Kammann, C., Grünhage, L., Müller, C., 2012. Simple biotoxicity tests for evaluation of carbonaceous soil additives: Establishment and reproducibility of four test procedures. J. Environ. Qual. 41, 1023-1032.

Chahartaghi, M., Langel, R., Scheu, S., Ruess, L., 2005. Feeding guilds in Collembola based on nitrogen stable isotope ratios. Soil Biol. Biochem. 37, 1718-1725.

Chan, K.Y., Van Zwieten, L., Meszaros, I., Downie, A., Joseph, S., 2008. Using poultry litter biochars as soil amendments. Soil Res. 46, 437-444.

Chelinho, S., Domene, X., Campana, P., Natal-da-Luz, T., Scheffczyk, A., Römbke, J., Andrés, P., Sousa, J.P., 2011. Improving ecological risk assessment in the Mediterranean area: selection of reference soils and evaluating the influence of soil properties on avoidance and reproduction of two oligochaete species. Environ. Toxicol. Chem. 30, 1050-1058.

Crouau, Y., Chenon, P., Gisclard, C., 1999. The use of Folsomia candida (Collembola, Isotomidae) for the bioassay of xenobiotic substances and soil pollutants. App. Soil Ecol. 12, 103-111.

Didden, W.A.M., Römbke, J., 2001. Enchytraeids as indicator organisms for chemical stress in terrestrial ecosystems. Ecotoxicol. Environ. Saf. 50, 25-43.

Domene, X., Chelinho, S., Campana, P., Natal-da-Luz, T., Alcañiz, J.M., Andrés, P., Römbke, J., Sousa, P., 2011. Influence of soil properties on the performance of Folsomia candida: implications for its use in soil ecotoxicology testing. Environ. Toxicol. Chem. 30, 1497-1505.

Domene, X., Colón, J., Uras, M.V., Izquierdo, R., Àvila, A., Alcañiz, J.M., 2010. Role of soil properties in sewage sludge toxicity to soil collembolans. Soil Biol. Biochem. 42, 1982-1990.

Domene, X., Mattana, S., Hanley, K., Enders, A., Lehmann, J., 2014. Medium-term effects of corn biochar addition on soil biota activities and functions in a temperate soil cropped to corn. Soil Biol. Biochem. 72, 152-162. 
Domene, X., Natal-da-Luz, T., Alcañiz, J.M., Andrés, P., Sousa, J.P., 2007. Feeding inhibition in the soil collembolan Folsomia candida as an endpoint for the estimation of organic waste ecotoxicity. Environ. Toxicol. Chem. 26, 1538-1544.

Ennis, C.J., Evans, A.G., Islam, M., Ralebitso-Senior, K., Senior, E., 2012. Biochar: carbon sequestration, land remediation, and impacts on soil microbiology. Crit. Rev. Env. Sci. Technol. 42, 2311-2364.

Fountain, M.T., Hopkin, S.P., 2005. Folsomia candida (Collembola): A “Standard” soil arthropod. Annu. Rev. Entomol. 50, 201-222.

Frey, S.D., Elliott, E.T., Paustian, K., 1999. Bacterial and fungal abundance and biomass in conventional and no-tillage agroecosystems along two climatic gradients. Soil Biol. Biochem., 31, 573-585.

Güereña, D., Lehmann, J., Hanley, K., Enders, A., Hyland, C., Riha, S., 2013. Nitrogen dynamics following field application of biochar in a temperate North American maizebased production system. Plant Soil 365, 239-254.

Hagner, M., 2013. Potential of the slow pyrolysis products birch tar oil, wood vinegar and biochar in sustainable plant protection: pesticidal effects, soil improvement and environmental risks. Academic Dissertation in Environmental Ecology. Department of Environmental Sciences, Faculty of Biological and Environmental Sciences, University of Helsinki, Finland.

Hale, S.E., Jensen, J., Jakob, L., Oleszczuk, P., Hartnik, T., Henriksen, T., Okkenhaug, G., Martinsen, V., Cornelissen, G., 2013. Short-term effect of the soil amendments activated carbon, biochar, and ferric oxyhydroxide on bacteria and invertebrates. Environ. Sci. Technol. 47, 8674-8683.

ISO (International Organization for Standardization), 1999. Soil Quality - Inhibition of reproduction of Collembola (Folsomia candida) by soil pollutants. ISO Guideline 11267 International Standardization Organization, Geneva, Switzerland.

ISO (International Organization for Standardization), 2004. Soil Quality - Effects of pollutants on Enchytraeidae (Enchytraeus sp) - Determination of effects on reproduction and survival. ISO Guideline 16387 International Standardization organization, Geneva, Switzerland. 
ISO (International Organization for Standardization), 2011. Soil quality - Avoidance test for testing the quality of soils and effects of chemicals - Part 2: Test with collembolans (Folsomia candida). ISO Guideline 17512-2 International Standardization organization, Geneva, Switzerland.

Jin, H., 2010. Characterization of microbial life colonizing biochar and biocharamended soils. PhD Dissertation.Cornell University, Ithaca, NY, USA.

Lehmann, J., Rillig, M.C., Thies, J., Masiello, C.A., Hockaday, W.C., Crowley, D., 2011. Biochar effects on soil biota - A review. Soil Biol. Biochem. 43, 1812-1836.

Li, D., Hockaday, W.C., Masiello, C.A., Alvarez, P.J.J. 2011. Earthworm avoidance of biochar can be mitigated by wetting. Soil Biol. Biochem. 43, 1732-1737.

Liesch, A.M., Weyers, S.L., Gaskin, J.W., Das, K.C., 2010. Impact of two different biochars on earthworm growth and survival. Ann. Environ. Sci. 4, 1-9.

Loureiro, S., Soares, A.M.V.M., Nogueira, A.J.A., 2005. Terrestrial avoidance behaviour tests as screening tool to assess soil contamination. Environ. Pollut. 138, 121-131.

Lukkari, T., Haimi, J., 2005. Avoidance of Cu-and Zn-contaminated soil by three ecologically different earthworm species. Ecotoxicol. Env. Saf. 62, 35-41.

Major, J,. 2009. A guide to conducting biochar trials.The International Biochar Initiative. http://www.biochar-international.org [accessed on 18 July 2014].

Marks, E.A.N., 2013. Biochar effects on soil quality as evaluated by physical, chemical, and biological parameters. PhD Dissertation, CREAF-Department of Animal Biology, Plant Biology and Ecology, Autonomous University of Barcelona, Cerdanyola del Vallès, Barcelona, Spain.

Marks, E.A.N., Mattana, S., Alcañiz, J.M., Domene, X., 2014. Biochars provoke diverse soil mesofauna reproductive responses in laboratory bioassays. Eur. J. Soil Biol. 60, 104-111.

McCormack, S., Ostle, N., Bardgett, R.D., Hopkin, D.W., Van Bergen, A.J., 2013. Biochar in bioenergy cropping systems: impacts on soil faunal communities and linked ecosystem processes. GCB Bioenergy 5, 81-95. 
Moore, J.C., Ingham, E.R., Coleman, D.C., 1987. Inter- and intraspecific feeding selectivity of Folsomia candida (Willem) (Collembola, Isotomidae) on fungi. Biol. Fertil. Soils 5, 6-12.

Natal-da-Luz, T., Amorim, M.J., Römbke, J., Sousa, J.P., 2008a. Avoidance tests with earthworms and springtails: defining the minimum exposure time to observe a significant response. Ecotoxicol. Environ. Saf. 71, 545-551.

Natal-da-Luz, T., Domene, X., Scheffczyk, A., Sousa, J.P., 2009. Earthworm avoidance tests. In: Römbke, J., Moser, J. (eds) Ecotoxicological characterization of waste. Springer New York, USA, pp. 191-196.

Natal-da-Luz, T., Römbke, J., Sousa, J.P., 2008b. Avoidance tests in site-specific risk assessment - influence of soil properties on the avoidance response of Collembola and earthworms. Environ. Toxicol. Chem. 27, 1112-1117.

Owojori, O.J., Reinecke, A.J., Voua-Otomo, P., Reinecke, S.A., 2009. Comparative study of the effects of salinity on life-cycle parameters of four soil-dwelling species (Folsomia candida, Enchytraeus doerjesi, Eisenia fetida and Aporrectodea caliginosa). Pedobiologia 52, 351-360.

Pell, M., Stenström, J., Granhall, U., 2006. Soil respiration. In: Bloem, J., Hopkins, D.W., Benedetti, A.(eds) Microbiological methods for assessing soil quality. CABI Publishing. King's Lynn, UK.

Phillips, D.H., Foss, J.E., Buckner, E.R., Evans, R.M., FitzPatrick, E.A., 2000.

Response of surface horizons in an oak forest to prescribed burning. Soil Sci. Soc. Am. J. 64, 754-760.

Pietikäinen, J., Kiikkilä, O., Fritze, H., 2000. Charcoal as a habitat for microbes and its effects on the microbial community of the underlying humus.Oikos 89, 231-242.

Ponge, J., Topoliantz, S., 2006. Ingestion of charcoal by the Amazonian earthworm Pontoscolex corethrurus: A potential for tropical soil fertility. Soil Biol. Biochem. 38, 2008-2009.

Rajkovich, S., Enders, A., Hanley, K., Hyland, C., Zimmerman, A.R., Lehmann, J., 2012. Corn growth and nitrogen nutrition after additions of biochars with varying properties to a temperate soil. Biol. Fertil. Soils 48, 271-284. 
Römbke, J., 2003. Ecotoxicological laboratory tests with enchytraeids: A review: The 7th international symposium on earthworm ecology• Cardiff· Wales· 2002. Pedobiologia 47, 607-616.

Römbke, J., Moser, T., 2002. Validating the enchytraeid reproduction test: organisation and results of an international ringtest. Chemosphere 46, 1117-1140.

Salmon, S., Ponge, J.F., 2001. Earthworm excreta attract soil springtails: laboratory experiments on Heteromurus nitidus (Collembola: Entomobryidae). Soil Biol. Biochem. 33, 1959-1969.

Schrader, G., Metge, K., Bahadir, M., 1998. Importance of salt ions in ecotoxicological tests with soil arthropods. App. Soil Ecol. 7, 189-193.

Seastedt, T.R., 1984. The role of microarthropods in decomposition and mineralization processes. Ann. Rev. Entomol. 29, 25-46.

Steiner, C., Teixeira, W.G., Lehmann, J., Zech, W., 2004. Microbial response to charcoal amendments of highly weathered soils and Amazonian Dark Earths in Central Amazonia - preliminary results. In: Glaser, B., Woods, W.I. (eds) Amazonian Dark Earths: Explorations in Time and Space. Springer, Berlin, Germany, pp. 195212.

Tammeorg, P., Parviainen, T., Nuutinen, V., Simojoki, A., Vaara, E., Helenius, J., 2014. Effects of biochar on earthworms in arable soil: avoidance test and field trial in boreal loamy sand. Agric. Ecosyst. Environ. 191, 150-157.

Thimm, T., Hoffmann, A., Borkott, H., Munch, J.C., Tebbe, C.C., 1998. The gut of the soil microarthropod Folsomia candida (Collembola) is a frequently changeable but selective habitat and a vector for microorganisms. App. Environ. Microb. 64, 26602669.

Topoliantz, S., Ponge, J., 2005. Charcoal consumption and casting activity by Pontoscolex corethrurus (Glossoscolecidae). Appl. Soil Ecol. 28, 217-224.

Urbásek, F., Rusek, J., 1994. Activity of digestive enzymes in seven species of Collembola (Insecta, Entognatha). Pedobiologia 38, 400-406. 
Wiedner, K., Glaser, B., 2013. Biochar-fungi interactions in soils. In: Ladygina, N., Rineau, F. (eds) Biochar and soil biota. CRC Press-Taylor \& Francis Group, Boca Raton, FL, USA. pp. 69-99.

Zhang, X.-K., Li, Q., Liang, W.-J., Zhang, M., Bao, X.-L., Xie, Z.-B., 2013. Soil nematode response to biochar addition in a Chinese wheat field. Pedosphere 23, 98103. 
Table 1. GLM of the avoidance percentage in F. candida as explained by the unstandardized (left) and the standardized (right) soil physico-chemical and biological properties; $M B=$ microbial biomass.

\begin{tabular}{ccccc}
\hline & Estimate & Std. Error & t value & $\operatorname{Pr}(>|\mathbf{t}|)$ \\
\hline Intercept & 96.06141 & 22.15797 & 4.335 & $0.00045^{*}$ \\
MB & -0.10648 & 0.03483 & -3.057 & $0.00713^{*}$ \\
$\mathbf{N H}_{4}-\mathbf{N}$ & -2.81663 & 1.13647 & -2.478 & $0.02398^{*}$ \\
\hline
\end{tabular}

\begin{tabular}{ccccc}
\hline & Estimate & Std. Error & t value & $\operatorname{Pr}(>|\mathbf{t}|)$ \\
\hline Intercept & -250.36 & 112.702 & -2.221 & $0.042133^{*}$ \\
stdBr & -4.527 & 1.098 & -4.124 & $0.000901^{*}$ \\
stdMB & -67.083 & 23.82 & -2.816 & $0.013027^{*}$ \\
& & & & \\
stdNH $_{4}-\mathrm{N}$ & -21.541 & 8.869 & -2.419 & $0.028752^{*}$ \\
stdpH & 377.31 & 131.273 & 2.874 & $0.011584^{*}$ \\
\hline
\end{tabular}

Null deviance: 10861 on 19 degrees of freedom

Residual deviance: 5962 on 17 degrees of freedom AIC: 178.71

Null deviance: 10861.4 on 19 degrees of freedom $\mathbf{R}^{2}: 0.45$

Residual deviance: 3617.6 on 15 degrees of freedom AIC: 172.71

$\mathbf{R}^{2}: 0.67$ 
Table 2. GLM of the avoidance percentage in E. crypticus as explained by the unstandardized (left) and the standardized (right) soil physicochemical and biological properties.

\begin{tabular}{ccccc}
\hline & Estimate & Std. Error & t value & $\operatorname{Pr}(>|\mathbf{t}|)$ \\
\hline Intercept & -326.723 & 102.512 & -3.187 & $0.00573^{*}$ \\
NH $_{4}-\mathrm{N}$ & -4.633 & 1.364 & -3.396 & $0.00369^{*}$ \\
\hline
\end{tabular}

\begin{tabular}{ccccc}
\hline & Estimate & Std. Error & t value & $\operatorname{Pr}(>|\mathbf{t}|)$ \\
\hline Intercept & -3.717 & 7.256 & -0.512 & 0.615 \\
stdNH $_{\mathbf{4}} \mathrm{N}$ & -15.907 & 9.357 & -1.700 & 0.106 \\
\hline
\end{tabular}

Null deviance: 10100.6 on 19 degrees of freedom

Residual deviance: 9406.8 on 18 degrees of freedom

AIC: 185.83

$\mathbf{R}^{2}: 0.06$

Null deviance: 10100.6 on 19 degrees of freedom Residual deviance: 8703.2 on 18 degrees of freedom AIC: 184.27

$\mathbf{R}^{2}: 0.13$ 

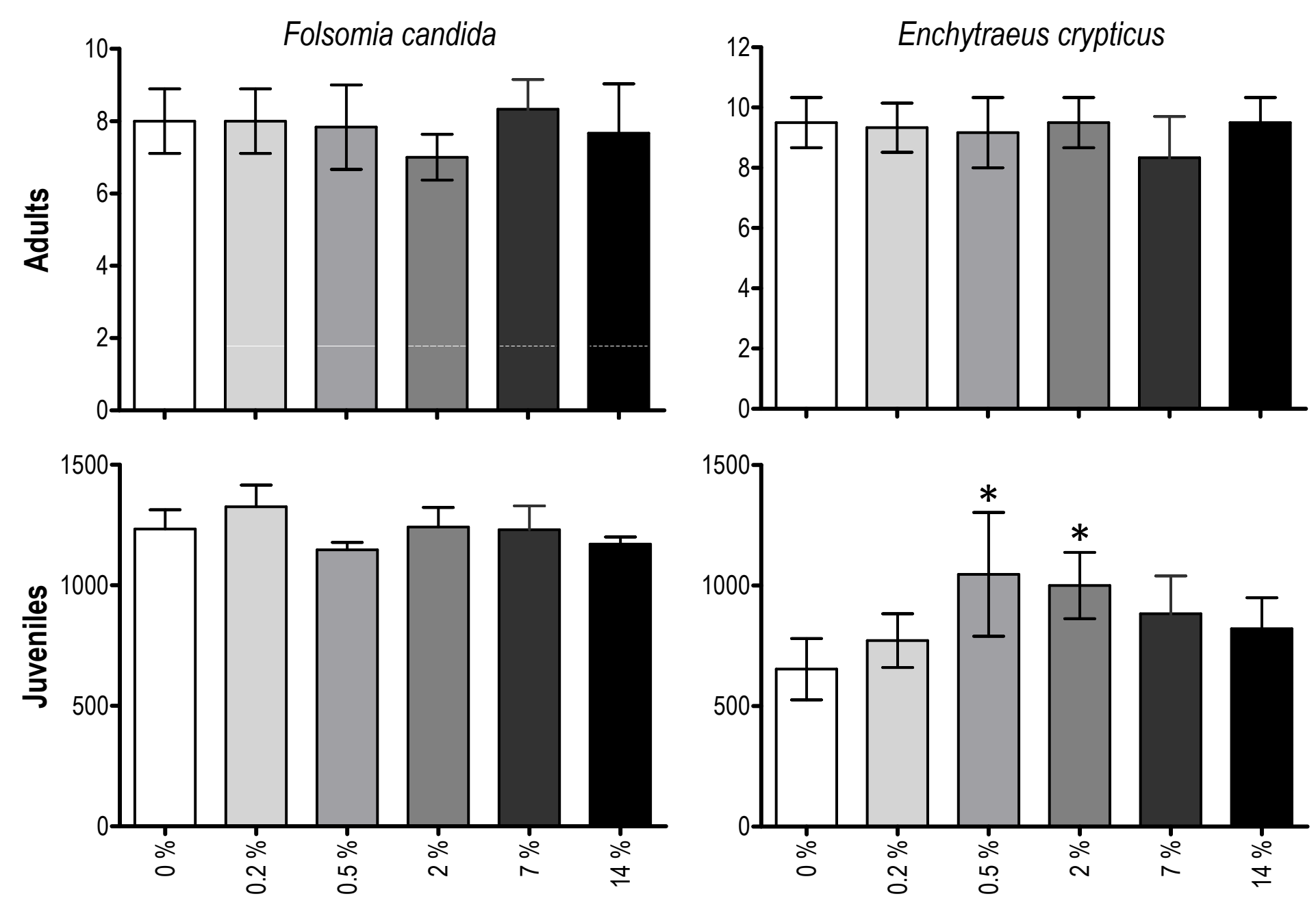

Biochar addition rate $(\%, w / w)$ 

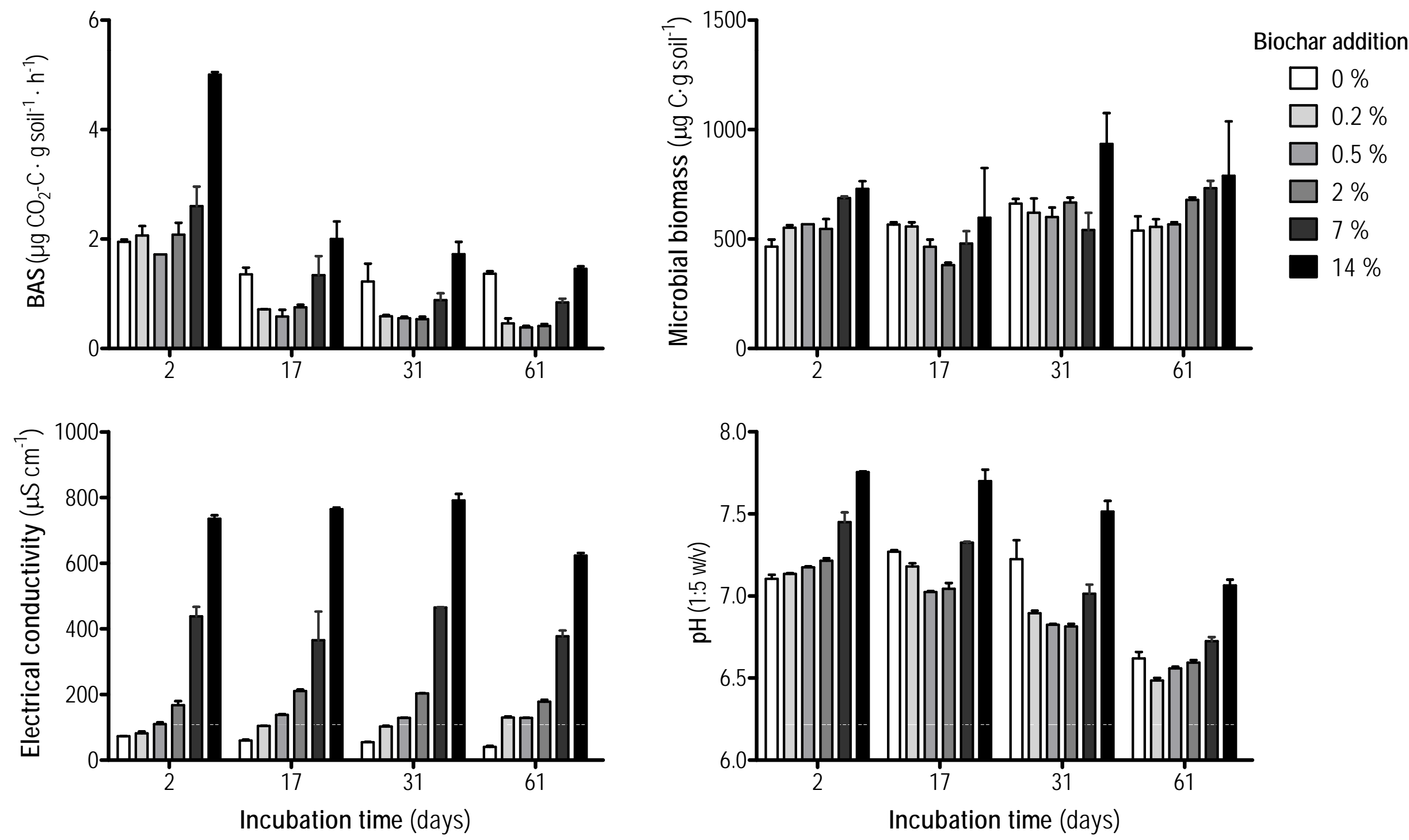


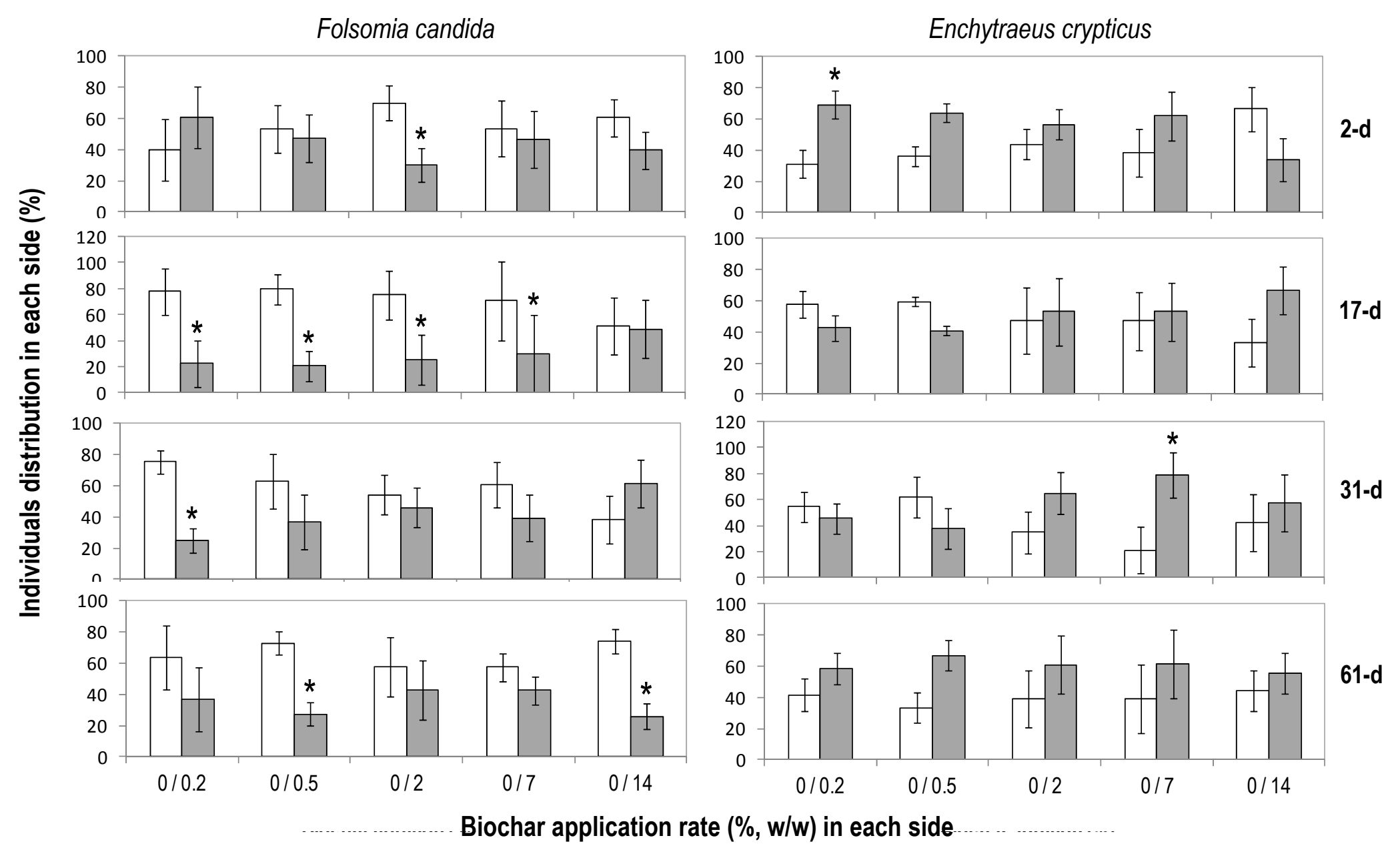



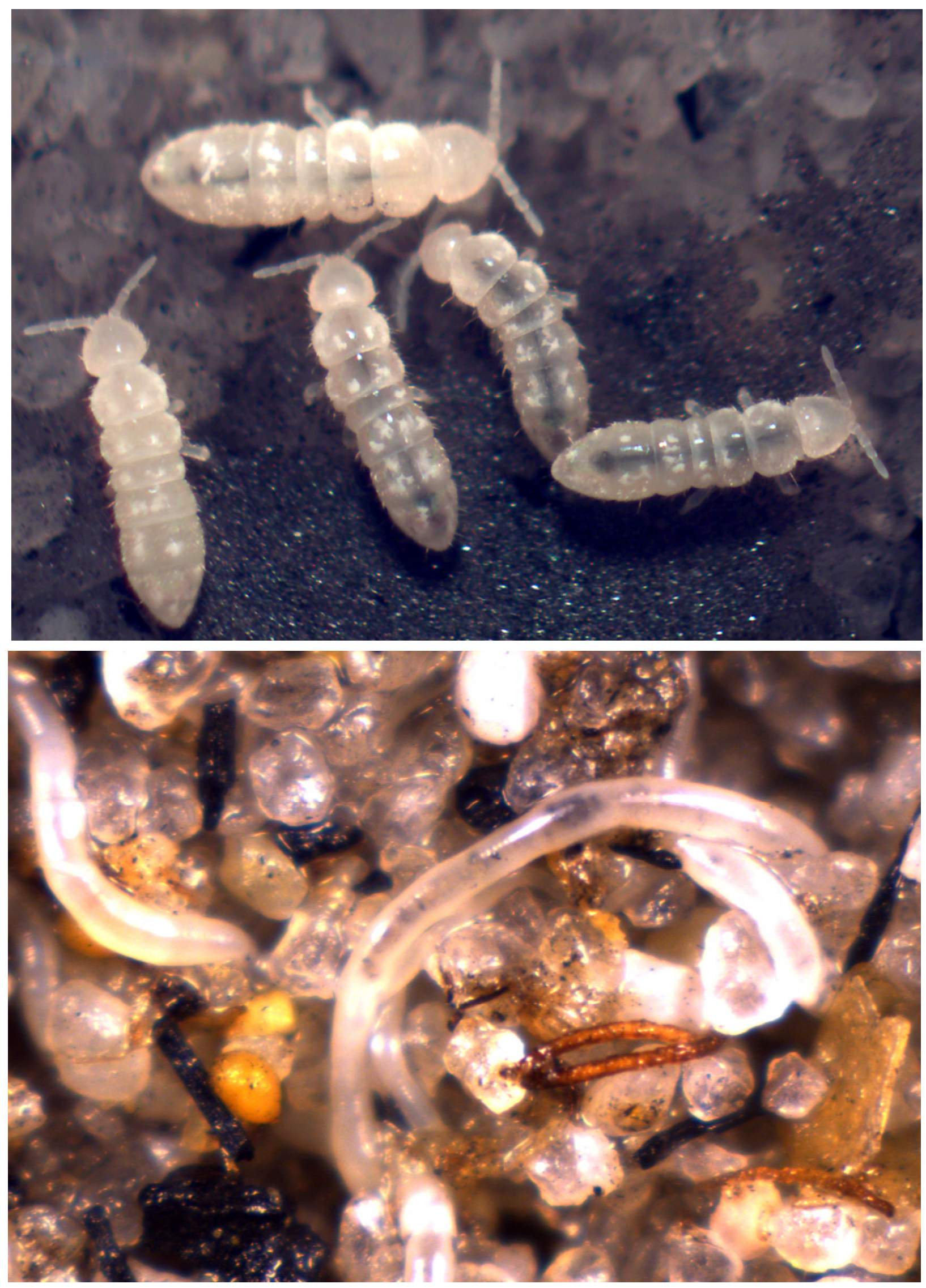

Supplementary Figure S1. F. candida (above) and E. crypticus (below) showing biochar ingestion, easily observed as a dark gut content, after $24 \mathrm{~h}$ in moistened $1 \%(\mathrm{w} / \mathrm{w})$ mixtures of corn stover biochar with quartz sand (washed sea sand, thick grain technical grade, Panreac). 

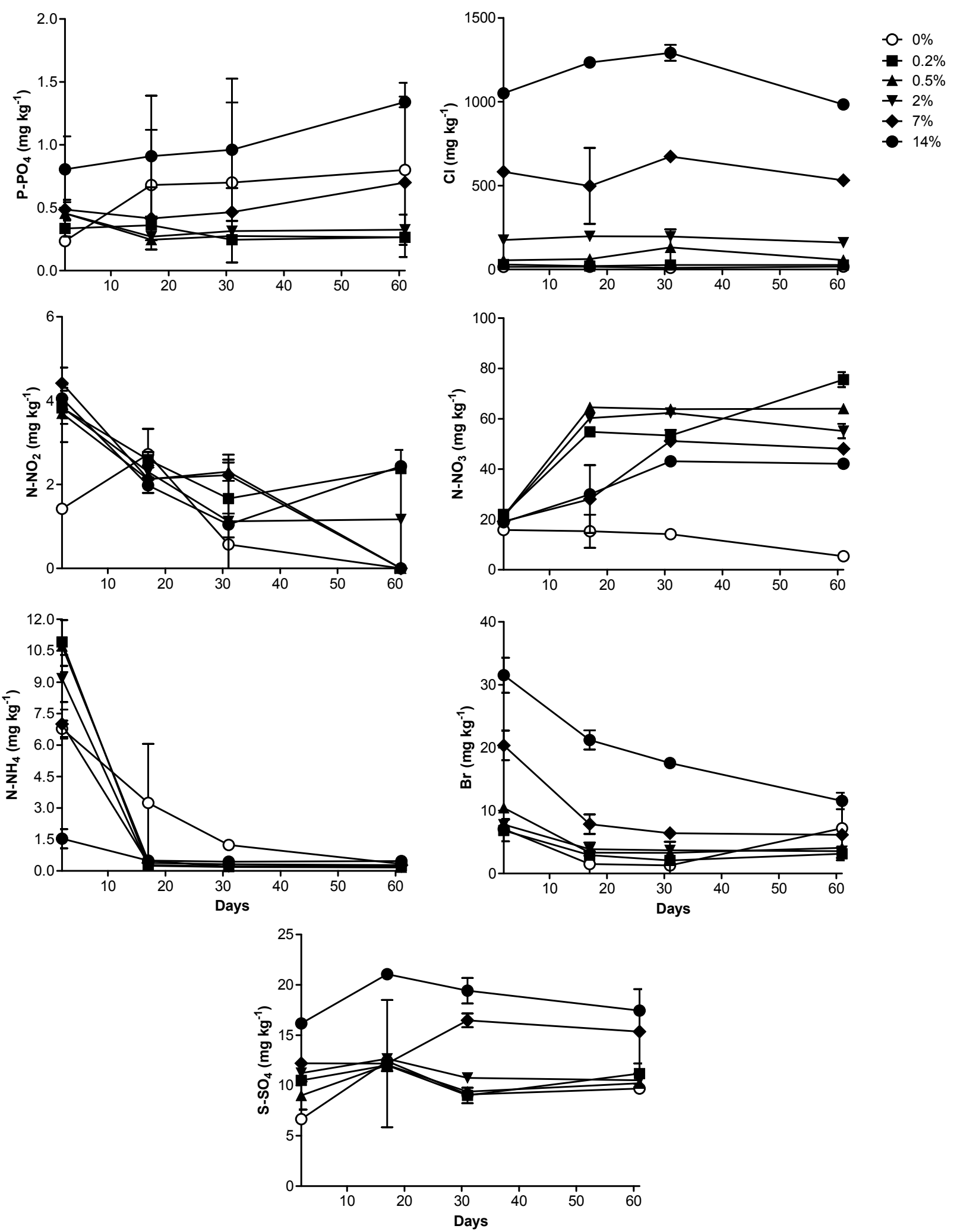

Supplementary Figure S2. Variation of soluble ion content in the different soil-biochar mixtures during a 60-d incubation; $n=2$. 
Supplementary Table S1. pH, electrical conductivity and soluble ionic and elemental content in 1:5 aqueous extracts soil mixtures with corn stover biochar applied at increasing addition rates (expressed as \%, w/w) at the end of the fauna reproduction tests after $28 \mathrm{~d}$ of incubation; $\mathrm{n}=2$.

\begin{tabular}{|c|c|c|c|c|c|c|c|}
\hline Parameter & Units & $0 \%$ & $0.2 \%$ & $0.5 \%$ & $2.0 \%$ & $7.0 \%$ & $14 \%$ \\
\hline $\mathrm{pH}$ & & 7.0100 & 6.9400 & 6.8600 & 6.8100 & 6.8000 & 6.9200 \\
\hline $\mathrm{EC}$ & $\mu S \mathrm{~cm}^{-1}$ & 111.90 & 126.20 & 135.50 & 228.00 & 467.00 & 938.00 \\
\hline $\mathrm{PO}_{4}-\mathrm{P}$ & $\mathrm{mg} \mathrm{kg}^{-1}$ & 0.3316 & 0.2272 & 0.2731 & 0.2118 & 0.6169 & 1.4297 \\
\hline $\mathrm{Cl}$ & $\mathrm{mg} \mathrm{kg}^{-1}$ & 13.803 & 33.562 & 58.966 & 230.98 & 808.31 & 1499.4 \\
\hline $\mathrm{Br}$ & $\mathrm{mg} \mathrm{kg}^{-1}$ & 0.0647 & 4.0128 & 3.6168 & 4.4405 & 8.5992 & 20.385 \\
\hline $\mathrm{NO}_{2-\mathrm{N}}$ & $\mathrm{mg} \mathrm{kg}^{-1}$ & 0.9616 & 1.8064 & 2.4328 & 2.2935 & 0.0000 & 2.1546 \\
\hline $\mathrm{NO}_{3}-\mathrm{N}$ & $\mathrm{mg} \mathrm{kg}^{-1}$ & 84.423 & 76.510 & 73.672 & 64.910 & 51.4491 & 41.450 \\
\hline $\mathrm{NO} 2-\mathrm{N}+\mathrm{NO}_{3}-\mathrm{N}$ & $\mathrm{mg} \mathrm{kg}^{-1}$ & 85.384 & 78.316 & 76.105 & 67.203 & 51.4491 & 43.604 \\
\hline $\mathrm{NH}_{4}-\mathrm{N}$ & $\mathrm{mg} \mathrm{kg}^{-1}$ & 0.1969 & 0.1723 & 0.0739 & 0.0492 & 0.0754 & 0.1818 \\
\hline $\mathrm{SO}_{4}-\mathrm{S}$ & $\mathrm{mg} \mathrm{kg}^{-1}$ & 13.911 & 11.675 & 12.087 & 15.215 & 15.2577 & 21.194 \\
\hline $\mathrm{Al}$ & $\mathrm{mg} \mathrm{kg}^{-1}$ & 1.6044 & 1.5039 & 0.7196 & 1.4401 & 2.0380 & 2.1714 \\
\hline As & $\mathrm{mg} \mathrm{kg}^{-1}$ & 0.0000 & 0.0000 & 0.0000 & 0.0000 & 0.0000 & 0.0000 \\
\hline B & $\mathrm{mg} \mathrm{kg}^{-1}$ & 0.7025 & 0.8182 & 0.5537 & 0.3784 & 0.7117 & 0.6036 \\
\hline $\mathrm{Ba}$ & $\mathrm{mg} \mathrm{kg}^{-1}$ & 0.0196 & 0.0186 & 0.0149 & 0.0249 & 0.0421 & 0.0374 \\
\hline $\mathrm{Ca}$ & $\mathrm{mg} \mathrm{kg}^{-1}$ & 21.443 & 21.170 & 19.514 & 18.965 & 27.780 & 21.432 \\
\hline Cd & $\mathrm{mg} \mathrm{kg}^{-1}$ & 0.0018 & 0.0000 & 0.0000 & 0.0004 & 0.0000 & 0.0000 \\
\hline $\mathrm{Cd}$ & $\mathrm{mg} \mathrm{kg}^{-1}$ & 0.0007 & 0.0007 & 0.0000 & 0.0017 & 0.0001 & 0.0004 \\
\hline Co & $\mathrm{mg} \mathrm{kg}^{-1}$ & 0.0005 & 0.0000 & 0.0000 & 0.0027 & 0.0008 & 0.0000 \\
\hline $\mathrm{Cr}$ & $\mathrm{mg} \mathrm{kg}^{-1}$ & 0.0023 & 0.0018 & 0.0006 & 0.0017 & 0.0018 & 0.0026 \\
\hline $\mathrm{Cu}$ & $\mathrm{mg} \mathrm{kg}^{-1}$ & 0.0000 & 0.0000 & 0.0000 & 0.0000 & 0.0000 & 0.0000 \\
\hline $\mathrm{Fe}$ & $\mathrm{mg} \mathrm{kg}^{-1}$ & 2.0670 & 1.8235 & 0.8496 & 1.7351 & 2.1710 & 2.4458 \\
\hline $\mathrm{K}$ & $\mathrm{mg} \mathrm{kg}^{-1}$ & 4.7271 & 7.0413 & 11.374 & 49.101 & 271.59 & 457.75 \\
\hline $\mathrm{Mg}$ & $\mathrm{mg} \mathrm{kg}^{-1}$ & 4.8928 & 4.9932 & 4.3737 & 4.5925 & 8.2697 & 7.9685 \\
\hline $\mathrm{Mn}$ & $\mathrm{mg} \mathrm{kg}^{-1}$ & 0.0217 & 0.0183 & 0.0089 & 0.0200 & 0.0225 & 0.0254 \\
\hline Mo & $\mathrm{mg} \mathrm{kg}^{-1}$ & 0.0048 & 0.0026 & 0.0004 & 0.0000 & 0.0000 & 0.0013 \\
\hline $\mathrm{Na}$ & $\mathrm{mg} \mathrm{kg}^{-1}$ & 2.7209 & 3.0559 & 2.3487 & 2.7343 & 5.9479 & 6.8848 \\
\hline $\mathrm{Ni}$ & $\mathrm{mg} \mathrm{kg}^{-1}$ & 0.0053 & 0.0027 & 0.0028 & 0.0025 & 0.0031 & 0.0027 \\
\hline $\mathrm{P}$ & $\mathrm{mg} \mathrm{kg}^{-1}$ & 0.2063 & 0.1194 & 0.1155 & 0.1348 & 0.2274 & 0.3766 \\
\hline $\mathrm{Pb}$ & $\mathrm{mg} \mathrm{kg}^{-1}$ & 0.0000 & 0.0000 & 0.0550 & 0.0472 & 0.0047 & 0.0000 \\
\hline $\mathrm{S}$ & $\mathrm{mg} \mathrm{kg}^{-1}$ & 3.4080 & 3.3040 & 2.7422 & 2.6389 & 3.8319 & 4.0746 \\
\hline Se & $\mathrm{mg} \mathrm{kg}^{-1}$ & 0.0302 & 0.0318 & 0.0240 & 0.0339 & 0.0144 & 0.0160 \\
\hline $\mathrm{Si}$ & $\mathrm{mg} \mathrm{kg}^{-1}$ & 3.8345 & 3.8345 & 1.9764 & 3.1728 & 6.4618 & 7.4585 \\
\hline $\mathrm{Sr}$ & $\mathrm{mg} \mathrm{kg}^{-1}$ & 0.0344 & 0.0346 & 0.0325 & 0.0365 & 0.0664 & 0.0563 \\
\hline
\end{tabular}




\begin{tabular}{clllllll}
$\mathrm{Ti}$ & $\mathrm{mg} \mathrm{kg}^{-1}$ & 0.0345 & 0.0302 & 0.0124 & 0.0269 & 0.0335 & 0.0425 \\
$\mathrm{~V}$ & $\mathrm{mg} \mathrm{kg}^{-1}$ & 0.0045 & 0.0036 & 0.0027 & 0.0035 & 0.0047 & 0.0058 \\
$\mathrm{Y}$ & $\mathrm{mg} \mathrm{kg}^{-1}$ & 0.0013 & 0.0004 & 0.0002 & 0.0006 & 0.0006 & 0.0008 \\
$\mathrm{Zn}$ & $\mathrm{mg} \mathrm{kg}^{-1}$ & 0.0125 & 0.0080 & 0.0063 & 0.0127 & 0.0074 & 0.0102 \\
\hline
\end{tabular}


Supplementary Table S2. Physico-chemical and biological properties in the different soil-biochar mixtures and along the incubation; $\mathrm{n}=2$.

\begin{tabular}{|c|c|c|c|c|c|c|c|c|c|c|c|c|c|c|}
\hline $\begin{array}{c}\text { Incubation } \\
\text { days }\end{array}$ & $\begin{array}{c}\begin{array}{c}\text { Biochar } \\
\text { application } \\
\text { rate }\end{array} \\
\%, \mathrm{w} / \mathrm{w} \\
\end{array}$ & Replicate & $\begin{array}{c}\text { Moisture } \\
\% \\
\end{array}$ & $\begin{array}{c}\text { water pH } \\
1: 5(\mathrm{w} / \mathrm{v})\end{array}$ & $\begin{array}{c}\text { EC } \\
\mu \mathrm{S} \mathrm{cm}^{-1}\end{array}$ & $\begin{array}{l}\mathbf{P O}_{4}-\mathbf{P} \\
\mathrm{mg} \mathrm{kg}^{-1}\end{array}$ & $\begin{array}{c}\text { Br } \\
\mathrm{mg} \mathrm{kg}^{-1}\end{array}$ & $\begin{array}{c}\mathbf{C l} \\
\mathrm{mg} \mathrm{kg}^{-1}\end{array}$ & $\begin{array}{l}\mathrm{NO}_{2}-\mathbf{N} \\
\mathrm{mg} \mathrm{kg}^{-1}\end{array}$ & $\begin{array}{l}\mathrm{NO}_{3}-\mathbf{N} \\
\mathrm{mg} \mathrm{kg}^{-1}\end{array}$ & $\begin{array}{l}\mathbf{N H}_{4}-\mathbf{N} \\
\mathrm{mg} \mathrm{kg}^{-1}\end{array}$ & $\begin{array}{c}\mathrm{SO}_{4}-\mathrm{S} \\
\mathrm{mg} \mathrm{kg}^{-1}\end{array}$ & $\begin{array}{c}\text { BAS } \\
\mu \mathrm{g} \mathrm{CO} 2-\mathrm{C} \mathrm{g}^{-1} \cdot \mathrm{h}^{-1}\end{array}$ & $\begin{array}{c}\text { MCB } \\
\mu g \text { C g-1 }\end{array}$ \\
\hline \multirow{12}{*}{2} & 0 & 1 & 27.9 & 7.1 & 73.1 & 0.24 & 7.16 & 14.77 & 1.42 & 14.90 & 7.05 & 6.37 & 1.99 & 498.0 \\
\hline & & 2 & & 7.1 & 73.4 & 0.23 & 6.98 & 15.27 & 1.42 & 16.68 & 6.50 & 6.93 & 1.91 & 434.1 \\
\hline & 0.2 & 1 & 32.5 & 7.1 & 76.3 & 0.38 & 5.61 & 28.27 & 3.65 & 21.04 & 10.11 & 10.15 & 2.24 & 541.0 \\
\hline & & 2 & & 7.1 & 87.2 & 0.29 & 8.04 & 29.96 & 4.00 & 22.94 & 11.73 & 10.85 & 1.89 & 563.2 \\
\hline & 0.5 & 1 & 33.5 & 7.2 & 104.8 & 0.44 & 10.47 & 56.79 & 4.18 & 22.09 & 11.60 & 9.98 & 1.72 & 568.3 \\
\hline & & 2 & & 7.2 & 115.0 & 0.47 & 10.37 & 53.57 & 3.21 & 20.51 & 9.84 & 8.01 & 1.72 & 568.4 \\
\hline & 2 & 1 & 33.6 & 7.2 & 155.8 & 0.45 & 7.16 & 177.0 & 3.56 & 20.62 & 9.97 & 11.41 & 2.30 & 502.1 \\
\hline & & 2 & & 7.2 & 180.0 & 0.46 & 8.40 & 175.2 & 4.12 & 21.81 & 8.38 & 11.07 & 1.86 & 591.4 \\
\hline & 7 & 1 & 36.0 & 7.4 & 467.0 & 0.43 & 18.70 & 598.1 & 4.15 & 19.85 & 7.49 & 12.25 & 2.25 & 679.2 \\
\hline & & 2 & & 7.5 & 410.0 & 0.54 & 22.02 & 566.4 & 4.68 & 18.50 & 6.51 & 12.17 & 2.96 & 695.5 \\
\hline & 14 & 1 & 39.7 & 7.8 & 746.0 & 0.62 & 33.49 & 1043 & 3.87 & 19.12 & 1.86 & 16.03 & 4.96 & 694.0 \\
\hline & & 2 & & 7.8 & 724.0 & 0.99 & 29.55 & 1057 & 4.23 & 18.70 & 1.21 & 16.30 & 5.05 & 764.8 \\
\hline \multirow{10}{*}{17} & 0 & 1 & 30.9 & 7.3 & 62.6 & 0.99 & 2.93 & 16.66 & 2.29 & 19.94 & 1.25 & 12.36 & 1.48 & 555.1 \\
\hline & & 2 & & 7.3 & 56.7 & 0.37 & 0.07 & 15.27 & 3.15 & 10.66 & 5.23 & 12.46 & 1.23 & 576.9 \\
\hline & 0.2 & 1 & 32.0 & 7.2 & 103.4 & 0.37 & 2.73 & 19.10 & 2.72 & 54.31 & 0.26 & 11.60 & 0.72 & 538.6 \\
\hline & & 2 & & 7.2 & 105.1 & 0.35 & 3.13 & 20.70 & 2.46 & 55.31 & 0.29 & 12.40 & 0.71 & 576.9 \\
\hline & 0.5 & 1 & 32.8 & 7.0 & 140.6 & 0.25 & 3.48 & 62.85 & 2.13 & 65.27 & 0.38 & 12.08 & 0.46 & 497.7 \\
\hline & & 2 & & 7.0 & 136.1 & 0.24 & 3.14 & 61.49 & 2.11 & 63.80 & 0.59 & 12.00 & 0.71 & 431.2 \\
\hline & 2 & 1 & 32.6 & 7.0 & 207.0 & 0.28 & 3.11 & 195.5 & 2.19 & 59.50 & 0.24 & 12.37 & 0.71 & 370.2 \\
\hline & & 2 & & 7.1 & 215.0 & 0.26 & 4.61 & 199.8 & 2.41 & 61.12 & 0.24 & 12.95 & 0.80 & 392.1 \\
\hline & 7 & 1 & 35.0 & 7.3 & 278.0 & 0.24 & 6.74 & 338.0 & 2.19 & 18.54 & 0.39 & 7.70 & 0.99 & 536.5 \\
\hline & & 2 & & 7.3 & 453.0 & 0.59 & 8.93 & 658.1 & 2.08 & 37.63 & 0.36 & 16.65 & 1.69 & 423.4 \\
\hline
\end{tabular}




\begin{tabular}{|c|c|c|c|c|c|c|c|c|c|c|c|c|c|c|}
\hline & 14 & 1 & 41.8 & 7.6 & 760.0 & 0.57 & 20.14 & 1233 & 2.11 & 29.89 & 0.44 & 21.32 & 2.32 & 370.5 \\
\hline & & 2 & & 7.8 & 770.0 & 1.25 & 22.30 & 1235 & 1.85 & 30.05 & 0.54 & 20.80 & 1.68 & 824.3 \\
\hline & 0 & 1 & 30.7 & 7.3 & 55.6 & 1.15 & 0.88 & 12.88 & 1.09 & 14.00 & 1.25 & 9.33 & 1.55 & 640.3 \\
\hline & & 2 & & 7.1 & 53.6 & 0.25 & 1.67 & 7.390 & 0.05 & 14.26 & 1.22 & 8.89 & 0.90 & 684.0 \\
\hline & 0.2 & 1 & 30.9 & 6.9 & 105.0 & 0.23 & 4.17 & 27.96 & 2.32 & 54.87 & 0.20 & 9.56 & 0.61 & 685.6 \\
\hline & & 2 & & 6.9 & 100.3 & 0.26 & 0.00 & 25.90 & 1.01 & 51.81 & 0.23 & 8.46 & 0.57 & 555.5 \\
\hline & 0.5 & 1 & 31.5 & 6.8 & 127.9 & 0.27 & 2.98 & 56.33 & 2.15 & 63.52 & 0.20 & 9.40 & 0.58 & 644.5 \\
\hline & & 2 & & 6.8 & 129.9 & 0.28 & 3.60 & 208.2 & 2.46 & 64.08 & 0.20 & 9.38 & 0.53 & 558.2 \\
\hline \multirow[t]{11}{*}{31} & 2 & 1 & 31.6 & 6.8 & 204.0 & 0.32 & 3.79 & 193.3 & 2.25 & 62.01 & 0.18 & 10.67 & 0.58 & 689.0 \\
\hline & & 2 & & 6.8 & 203.0 & 0.31 & 3.56 & 199.8 & 0.00 & 62.74 & 0.20 & 10.83 & 0.49 & 644.9 \\
\hline & 7 & 1 & 35.2 & 7.0 & 466.0 & 0.33 & 6.32 & 676.8 & 2.26 & 51.67 & 0.33 & 16.96 & 1.01 & 463.3 \\
\hline & & 2 & & 7.1 & 464.0 & 0.60 & 6.50 & 669.5 & 2.19 & 50.65 & 0.30 & 15.99 & 0.76 & 620.0 \\
\hline & 14 & 1 & 41.3 & 7.5 & 771.0 & 0.56 & 17.80 & 1258 & 0.00 & 41.82 & 0.38 & 18.53 & 1.95 & 1075.8 \\
\hline & & 2 & & 7.6 & 811.0 & 1.36 & 17.33 & 1325 & 2.09 & 44.37 & 0.50 & 20.32 & 1.50 & 794.1 \\
\hline & 0 & 1 & 32.1 & 6.6 & 43.3 & 1.29 & 10.51 & 18.78 & 0.00 & 5.020 & 0.35 & 9.93 & 1.41 & 604.2 \\
\hline & & 2 & & 6.7 & 38.0 & 0.31 & 3.84 & 15.82 & 0.00 & 5.720 & 0.32 & 9.46 & 1.32 & 474.5 \\
\hline & 0.2 & 1 & 32.6 & 6.5 & 133.2 & 0.29 & 3.87 & 26.77 & 2.44 & 77.68 & 0.24 & 11.90 & 0.55 & 520.5 \\
\hline & & 2 & & 6.5 & 126.5 & 0.24 & 2.40 & 27.51 & 2.32 & 73.43 & 0.24 & 10.46 & 0.37 & 591.1 \\
\hline & 0.5 & 1 & 31.0 & 6.6 & 129.1 & 0.26 & 4.05 & 54.95 & 0.00 & 63.74 & 0.20 & 10.22 & 0.41 & 578.0 \\
\hline \multirow[t]{7}{*}{61} & & 2 & & 6.6 & 129.0 & 0.27 & 4.12 & 56.51 & 0.00 & 64.23 & 0.15 & 10.21 & 0.36 & 555.9 \\
\hline & 2 & 1 & 31.9 & 6.6 & 184.0 & 0.24 & 3.83 & 167.1 & 0.00 & 57.10 & 0.15 & 11.01 & 0.45 & 690.1 \\
\hline & & 2 & & 6.6 & 172.8 & 0.41 & 3.26 & 153.2 & 2.34 & 53.09 & 0.18 & 10.03 & 0.37 & 668.7 \\
\hline & 7 & 1 & 37.0 & 6.7 & 360.0 & 0.72 & 6.52 & 515.0 & 0.00 & 46.63 & 0.27 & 12.37 & 0.91 & 766.3 \\
\hline & & 2 & & 6.8 & 395.0 & 0.68 & 5.76 & 547.6 & 0.00 & 49.48 & 0.27 & 18.33 & 0.78 & 698.2 \\
\hline & 14 & 1 & 42.5 & 7.0 & 631.0 & 1.37 & 12.45 & 988.5 & 2.38 & 42.50 & 0.47 & 17.58 & 1.41 & 1037.9 \\
\hline & & 2 & & 7.1 & 615.0 & 1.31 & 10.61 & 979.2 & 2.49 & 41.80 & 0.47 & 17.29 & 1.50 & 539.9 \\
\hline
\end{tabular}

